\title{
PENYELESAIAN SENGKETA EKSPEDITUR TERHADAP KETERLAMBATAN DAN/ATAU HILANGNYA BARANG PADA KONSUMEN \\ (Studi Kasus PT. Pacific Express Cargo)
}

\author{
Michael Angelo (1) \\ michaelangelo90@gmail.com ${ }^{(1)}$
}

\section{Universitas Pendidikan Nasional}

\begin{abstract}
It is undeniable that transportation activities which are the main component in business activities must be inevitable from some conflicts, both damage and delays in shipping of goods which of course will harm consumers. The purpose of this study is to analyze how to request dispute and expeditor's responsibility for delays and / or requesting goods to consumers. The legal material used in this study is the primary legal material consisting of the Commercial Law Law, the Civil Law Law, Law No. 8 of 1999 concerning Consumer Protection, as well as several other legal materials such as secondary legal materials and tertiary legal materials. The results of the research that have been done show that the expeditor as the delivery of goods must be held responsible for the limited costs received by the customer because it is based on agreements made by the parties in accordance with the doctrine, confidentiality of the contract. agreed in the agreement. Article 19 paragraph 2 of Law No. 8 of 1999 concerning consumer protection, namely "reimbursement of money or the purchase of comparable or valued goods and / or services, or health care and / or compensation assistance in accordance with the requirements of applicable regulations.
\end{abstract}

Keywords: Consumer Protection, Cargo Forwarder, Dispute Resolution ABSTRAK
Tidak dapat dipungkiri kegiatan pengangkutan yang merupakan komponen
utama dalam kegiatan bisnis pasti tidak terhindarkan dari beberapa
permasalahan baik itu kehilangan, kerusakan, maupun keterlambatan
pengiriman barang yang tentu akan merugikan konsumen. Tujuan
Penelitian ini adalah untuk menganalisis bagaimana penyelesaian sengketa
dan tanggung jawab ekspeditur terhadap keterlambatan dan/atau hilangnya
barang pada konsumen. Bahan hukum yang digunakan dalam penelitian ini
adalah bahan hukum primer yang terdiri dari Kitab Undang-Undang Hukum
Dagang, Kitab Undang-Undang Hukum Perdata, Undang-Undang No. 8
tahun 1999 tentang Perlindungan Konsumen, serta beberapa bahan hukum
lainnya seperti bahan hukum sekunder dan bahan hukum tersier. Hasil
penelitian yang telah dilaksanakan menunjukan bahwa Ekspeditur selaku
penyelenggara pengiriman barang memiliki tanggung jawab yang terbatas
terhadap kerugian yang diterima oleh konsumen karena didasari dengan
perjanjian yang dibuat oleh para pihak hal tersebut sesuai dengan doktrin
privity of contract mengenai tanggung jawab pelaku usaha hanya sebatas
dengan apa yang disepakati dalam perjanjian. Bentuk ganti rugi yang
diberikan dijelaskan dalam Pasal 19 ayat 2 Undang-Undang No. 8 tahun
1999 tentang Perlindungan konsumen yaitu "pengembalian uang atau
penggantian barang dan/atau jasa yang sejenis atau setara nilainya, atau 
perawatan kesehatan dan/atau pemberian santunan yang sesuai dengan ketentuan peraturan perundang-undangan yang berlaku.

\section{Kata Kunci: Perlindungan Konsumen, Ekspeditur, Penyelesaian Sengketa.}

\section{PENDAHULUAN}

Dewasa Ini jasa pengangkutan sangat diperlukan untuk membantu aktivitas masyarakat baik itu mempermudah usaha masyarakat seperti dalam menjalankan suatu usaha pasti membutuhkan sarana pengangkutan yang dapat digunakan untuk mengirimkan barang kepada pembeli atau pun dalam pengangkutan penumpang dari satu daerah ke daerah lain. Setiap perusahaan tentu dalam bentuk atau bidang apapun terutama dibidang perdagangan , tidak mungkin berjalan dengan sebagai mestinya untuk memperoleh keuntungan tanpa adanya pengangkutan yang memungkinkan sampainya barang-barang hasil produksi dan perdagangan ditempat konsumen pada tepat waktu serta didalam keadaan utuh dan lengkap, sehingga konsumen dapat menggunakan barang-barang yang diperlukan tersebut. Produsen juga membutuhkan pengangkutan untuk menyalurkan barang produksinya kepada para konsumen. Badan Pusat Statistik Provinsi Bali mencatat jika hanya dihitung pengangkutan udara dari januari sampai dengan desember tahun 2017 mencapai 101.623 ton dan pada tahun 2018 terus meningkat sampai dengan 107.751 ton total berat barang yang diangkut. ${ }^{1}$ Hal tersebut membuktikan bahwa pengangkutan pada saat ini sangat dibutuhkan di dunia bisnis.

Kegiatan pengangkutan tersebut bukan hanya mengenai pengangkutan benda-benda tetapi juga pengangkutan orang. Kita lihat sendiri bahwa pengangkutan pada pokoknya berisikan perpindahan tempat, mengenai benda-benda maupun mengenai orang-orang, karena perpindahan itu mutlak diperlukan untuk meninggikan manfaat serta efisiensi. Menurut R. Soekardono menjelaskan bahwa pengangkutan adalah suatu perpindahan tempat baik itu perpindahan orang-orang maupun benda-benda dan juga perpindahan tersebut adalah mutlak untuk memberikan manfaat untuk meninggikan manfaat barang serta efisiensi. ${ }^{2}$

${ }^{1}$ https://bali.bps.go.id/pressrelease/2019/02/01/717229/perkembangantransportasi-udara-dan-laut-provinsi-bali-desember-2018.html(9/21/2019 8:46 PM)

${ }^{2}$ Ridwan Khairandy, Machsun Tabroni, Ery Arifuddin, dan Djohari Santoso, 1999, "Pengantar Hukum Dagang Indonesia", Jilid 1, Gama Media, Yogyakarta, h. 195 
Pengangkutan tersebut adalah gerakan dari tempat pengangkutan awal tersebut dilaksanakan sampai dengan tempat tujuan pengangkutan tersebut dakhiri.

Menurut H.M.N Purwosutjipto menjelaskan bahwa pengangkutan adalah perjanjian timbal balik antara pengangkut bersama dengan pengirim, yang dimana pengangkut sendiri mengikatkan diri dalam suatu perjanjian bersama dengan pengirim untuk menyelenggarakan pengangkutan barang dan atau orang dari tempat yang satu ke tempat lain dengan selamat dan/atau orang dari suatu tempat ke tempat tujuan tertentu dengan selamat, dan seorang pengirim tersebut wajib untuk membayarkan ongkos terhadap penggunaan jasa pengangkutan tersebut. ${ }^{3}$

Menurut Sri Rejeki Hartono menjelaskan bahwa pada dasarnya pengangkutan memiliki dua kegunaan utama yaitu:

1) Kegunaan Tempat (Place Utility)

Adanya kegiatan pengangkutan berarti terjadi perpindahan barang dari suatu tempat, dimana barang tadi dirasakan kurang bermanfaat, ketempat yang menyebabkan barang tadi menjadi lebih bermanfaat.

2) Kegunaan Waktu (Time Utility)

Adanya pengangkutan berarti dapat dimungkinkan terjadinya suatu perpindahan suatu barang dari suatu tempat ketempat lain dimana barang itu lebih diperlukan tepat pada waktunya. ${ }^{4}$

Mendengar pengangkutan pastinya tidak terlepas dari seorang ekspeditur dalam melaksanakan kegiatan tersebut. Di Bali salah satu perusahaan yang menyediakan jasa pengangkutan barang adalah PT Pacific Express Cargo yang kedudukannya sebagai ekspeditur. Menurut Reza Rivaldi selaku operasional PT. Pacific Express Cargo menjelaskan bahwa yang dimaksud dengan Ekspeditur adalah seorang yang mendapatkan kewenangan dari pengirim barang untuk melakukan pengurusan pengiriman barang baik itu dari pengepakan hingga pengiriman barang sampai tujuan. ${ }^{5}$ Kitab Undang-Undang Hukum Dagang

3 H.M.N Purwosutjipto, 2000, "Pengertian Pokok Hukum Dagang Indonesia, Hukum Pengangkutan" Cetakan ke 3, Djambatan, Jakarta,h. 60. h.154.

4 Zainal Asikin, 2014, "Hukum Dagang, Rajagrafindo Persada", Jakarta,

5 Wawancara dengan operasional PT Pacific Express Cargo, 12 September 2019. 
yang selanjutnya dapat disebut sebagai KUHD menjelaskan pula mengenai ekspeditur yang tercantum pada Pasal 86 ayat 1 bahwa ekspeditur bertugas menyelenggarakan jasa pengangkutan barang-barang bagi pihak pengirim, baik mengenai pengangkutan di darat, udara, maupun dilaut, terkait pelaksanaan pengangkutan tersebut dijelaskan oleh Reza Rivaldi selaku operasional PT Pacific Express Cargo bahwa pengangkutan hanya dapat terlaksana apabila para pihak telah sepakat terhadap hak, kewajiban serta konsekuensi dari dilaksanakannya kegiatan pengangkutan tersebut dalam suatu perjanjian yang biasanya dibuat secara lisan ${ }^{6}$ dan setelah perjanjian tersebut disepakati ekspeditur bertanggung jawab terhadap barang milik pengirim yang akan dikirimkan ketujuan dengan selamat. Tanggung jawab seorang ekspeditur dalam substansi hukum Indonesia sendiri telah diatur pada KUHD tepatnya pada Pasal 91 yang menjelaskan bahwa:

"Para pengangkut dan juragan kapal harus bertanggungjawab atas semua kerusakan yang terjadi pada barang-barang dagangan atau barangbarang yang telah diterima untuk diangkut, kecuali hal itu disebabkan oleh cacat barang itu sendiri, atau oleh keadaan di luar kekuasaan mereka, atau oleh kesalahan atau ketalaian pengirim atau ekspeditur sendiri."

Bentuk tanggung jawab ekspeditur selama kegiatan pengangkutan dilaksanakan dijelaskan oleh Pak Komang selaku Manager Marketing PT. Pacific Express Cargo bahwa ekspeditur bertanggung jawab dalam pengiriman barang dalam hal ini barang tersebut dikemas dengan struktur yang kuat serta disusun dengan rapi untuk menghindari kerusakan barang dan juga menganalisis akan waktu yang harus sampai ketempat konsumen berada baik itu menentukan kapan harus memesan transportasi dan terkait barang yang belum jadi yaitu terus menghubungi produsen barang tersebut agar barang dapat dikirimkan ke tempat penerima barang. PT Pacific Express Cargo selama menyelenggarakan kegiatan pengangkutan tidak selalu berjalan mulus adapun beberapa masalah yang pernah terjadi yakni pada maret 2017 dijelaskan bahwa terdapat kerusakan barang saat pengiriman barang adapun barang di dalamnya adalah guci antik yang strukturnya gampang pecah, telah terjadi pula kehilangan

6 Wawancara dengan operasional PT Pacific Express Cargo, 12 September 2019. 
barang saat pengiriman baju tekstil berlogo Billabong, serta keterlambatan pengiriman barang ketujuan yang tidak sesuai dengan apa yang diperjanjikan. Berdasarkan data kehilangan dan keterlambatan barang yang terjadi di PT Pacific Express Cargo dari tahun 2017 sampai 2019, yaitu pada tahun 2017 dari 88 pengangkutan yang dilaksanakan terdapat total 3 kasus kehilangan barang 13 keterlambatan pengiriman barang, 2018 terdapat 2 kasus kehilangan barang dan 17 kali keterlambatan pengiriman barang, dan pada tahun 2019 (terhitung sampai dengan bulan September 2019) terdapat 2 kasus kehilangan barang 15 kali keterlambatan pengiriman barang. Hal yang telah dijelaskan tersebut perlu diketahui bagaimana penyelesaian perselisihan barang tersebut beserta tanggung jawab dari seorang ekspeditur terhadap barang yang dikirim tersebut. Sehingga Adapun rumusan masalah yang dikaji dari latar belakang di atas adalah:

A. Bagaimana tanggung jawab PT. Pacific Express Cargo apabila terjadi keterlambatan ataupun hilangnya barang pada konsumen ?

B. Bagaimana penyelesaian sengketa PT. Pacific Express Cargo terhadap keterlambatan ataupun hilangnya barang pada konsumen?

\section{METODE PENELITIAN}

Jenis penelitian yang digunakan dalam penelitian ini penelitian secara empiris, dimana penelitian secara empiris atau dalam istilah lain dapat disebut sebagai penelitian hukum sosiologis atau disebut pula dengan penelitian dilapangan dengan menggunakan Data primer yakni Data yang diperoleh secara langsung dari sumber utama di lapangan, baik dari responden maupun informan, dimana data tersebut berasal dari observasi atau pengamatan secara langsung ke tempat kejadian dan melalui wawancara dan didukung dengan data sekunder yang terdiri dari bahan hukum primer, diperoleh dari Kitab Undang-Undang Hukum Dagang (KUHD), Kitab Undang-Undang Hukum Perdata (KUHPer), UndangUndang No. 8 tahun 1999 tentang Perlindungan Konsumen. Bahan Hukum Sekunder, diperoleh dari literatur, buku, dan data yang relevan dengan penelitian yang diangkat dan bahan hukum tersier, diperoleh dari internet sebagai tambahan bagi penulis untuk memuat informasi yang berkaitan 
dengan penulisan ini. Teknik Pengumpulan Data menggunakan Teknik Wawancara, dilakukan dengan cara mengajukan pertanyaan secara langsung oleh pewawancara kepada responden dan informan, pertanyaan tersebut dirancang secara sistematis guna mendapatkan jawaban yang sesuai dengan penelitian yang sedang dibahas dan Dokumentasi, dilakukan dengan melihat dan selanjutnya menganalisis dokumen yang dibuat oleh subjek sendiri atau oleh orang lain yang tergabung dalam penelitian ini sesuai dengan objek penelitian yang dibahas. Data yang telah terkumpul baik itu data primer maupun data sekunder maka data tersebut diolah secara kualitatif, Setelah melalui proses pengolahan data, kemudian data tersebut dianalisis dan disajikan secara deskriptif analisis. Arti dari deskriptif adalah pemaparan hal-hal penelitian secara sistematis dan menyeluruh menyangkut fakta yang berhubungan dengan permasalahan penelitian, sedangkan analisis adalah fakta yang berhubungan dengan penelitian dianalisis secara cermat sehingga kemudian didapatkan kesimpulan penelitian. Adapun Lokasi Penelitian ini dilakukan di PT. Pacific Express Cargo yang beralamat di Jalan Hang Tuah No. 1 - 3 X, Sanur Kaja, Denpasar Selatan, Renon, Kecamatan Denpasar Selatan., Kota Denpasar Provinsi Bali. Alasan penulis memilih lokasi tersebut karena PT. Pacific Express Cargo merupakan salah satu perusahaan pengangkutan terbesar di kota Denpasar.

\section{HASIL PENELITIAN DAN PEMBAHASAN}

\section{A. Tanggung Jawab PT. Pacific Express Cargo terhadap Keterlambatan dan/atau Hilangnya Barang Pada Konsumen.}

Tanggung jawab seorang ekspeditur dalam hal kerugian yang diterima oleh penerima barang sendiri sebelumnya telah dijelaskan pada Pasal 91 KUHD terkait pengganti kerugian terhadap kerusakan barang yang diterima dari dilaksanakannya kegiatan pengangkutan tersebut dan pada Undang-Undang No. 8 tahun 1999 tentang Perlindungan Konsumen tepatnya pada Pasal 19 ayat 1 menjelaskan bahwa "pelaku usaha dalam melaksanakan kegiatan usahanya patut memberikan pengganti kerugian atas, pencemaran, kerusakan dan/atau kerugian yang diterima oleh konsumen yang dapat disebabkan pada pengkonsumsian barang dan/atau jasa yang diperdagangkan dan/atau produksi dari seorang pelaku usaha 
tersebut".

PT Pacific guna menjaga barang yang menjadi tanggungannya terhadap pengirim pada awal pelaksanaan kegiatan pengangkutan tersebut pihak ekspeditur bersama dengan pengirim membuat perjanjian secara lisan mengenai hal-hal yang dilaksanakannya kegiatan pengangkutan baik sebelum, saat, maupun setelah barang telah sampai ketujuan, adapun beberapa hal yang menjadi pokok perjanjian tersebut adalah mengenai biaya penggunaan jasa pengangkutan, tanggung jawab seorang ekspeditur terhadap terlambatnya ataupun hilangnya barang selama pengangkutan dilaksanakan, maupun hak dan kewajiban pengirim dan ekspeditur. Dijelaskan oleh Pak Komang selaku Manager Marketing PT Pacific Express Cargo bahwa penyebab keterlambatan pengiriman barang sebagian besar terjadi karena hal yang tidak force majeure. ${ }^{7}$ Force majeure memiliki pengertian kejadian diluar kemampuan manusia yang tidak dapat terhindarkan dan menyebabkan pihak tidak dapat memenuhi kewajibannya dalam perjanjian, ${ }^{8}$ dalam kasus PT Pacific sendiri cuaca buruk merupakan penyebab utama transportasi pengangkutan seperti pesawat ataupun kapal tersebut delay sehingga pengiriman barang tertunda dan tidak dapat sampai ke tujuan sesuai dengan waktu yang ditentukan, sedangkan terkait hilangnya barang dijelaskan oleh Pak Komang selaku Manager Marketing PT Pacific yang merupakan penyebab utama adalah pencurian yang terjadi pada saat pemindahan barang ke kargo kapal. $^{9}$

Pertanggungjawaban ekspeditur terhadap kerugian yang diterima konsumen dalam undang-undang no. 8 tahun 1999 tentang perlindungan konsumen pada Pasal 4 poin ke 8 menjelaskan bahwa salah satu hak konsumen adalah hak untuk mendapatkan ganti rugi atau kompensasi dalam hal apabila barang yang telah diterima tidak sesuai dengan apa yang telah diperjanjikan bersama, Pasal tersebut menjelaskan bahwa ganti rugi harus diberikan oleh pelaku usaha terhadap kerugian yang diterima oleh konsumen. Pasal tersebut tidak menjelaskan secara penuh sebatas mana tanggung jawab seorang pelaku usaha dalam kasus ini ekspeditur. Dijelaskan oleh Pak Komang selaku manager marketing PT Pacific Express

7 Wawancara dengan manager marketing PT Pacific Express Cargo, 19 September 2019.

${ }^{8}$ https://id.wikipedia.org/wiki/Keadaan kahar(11/23/2019 11:53 AM)

9 Wawancara dengan manager marketing PT Pacific Express Cargo, 19 September 2019. 
bahwa dalam hal kerugian berupa kerusakan ataupun kehilangan yang diterima konsumen biasanya didasari dengan perjanjian yang disepakati para pihak yang mana biasanya di awal perjanjian dijelaskan kepada konsumen oleh PT Pacific secara lisan bahwa apabila terjadi kerugian baik itu kehilangan atau kerusakan pihak asuransilah yang bertanggung jawab terhadap kerusakan ataupun kehilangan barang tersebut dengan membayar premi sejumlah $2 \%$ dari nilai barang milik pengirim barang, adapun perusahaan asuransi yang bekerja sama dengan PT Pacific terkait terjadinya kerugian baik itu kehilangan ataupun kerusakan barang adalah Asuransi Mitra $^{10}$, pengganti kerugian tersebut dalam pasal 19 ayat 2 Undang-Undang No. 8 Tahun 1999 tentang Perlindungan konsumen telah menjelaskan bahwa "ganti rugi dapat berupa pengembalian uang atau penggantian barang dan/atau jasa yang sejenis atau setara nilainya, atau perawatan kesehatan dan/atau pemberian santunan yang sesuai dengan ketentuan peraturan perundang-undangan yang berlaku" dan terkait claim asuransi terhadap adanya kerusakan dan kehilangan barang tersebut dari pihak penerima barang dapat melampirkan foto terkait barang yang rusak ataupun barang yang hilang dan dari pihak PT Pacific sendiri akan memproses hasil dokumentasi berupa foto dari penerima barang dengan membuat surat claim asuransi terkait hilang ataupun rusaknya barang kepada Mitra Asuransi setelah itu pihak asuransi akan memproses pengganti kerugian kepada penerima barang sebesar kerugian yang diterima oleh penerima barang tersebut tetapi tidak melebihi $2 \%$ dari jumlah asuransi yang telah dibayarkan sebelumnya oleh pengirim barang dan apabila terjadi keterlambatan pengiriman barang upaya yang dilaksanakan oleh PT Pacific dijelaskan oleh Pak Komang selaku Manager Marketing PT Pacific Express Cargo adalah memberikan informasi terkait penyebab barang tersebut tidak dapat sampai ketujuan tepat waktu kepada penerima barang yang biasanya disebabkan oleh cuaca yang buruk dan terhadap hal tersebut bentuk tanggung jawab dari PT Pacific adalah terus memberitahukan kabar dari barang yang dikirimkan sampai ketujuan dan apabila terdapat hambatan diperjalanan pihak PT Pacific melakukan dokumentasi berupa foto dan komunikasi melalui aplikasi whatsapp untuk

10 Wawancara dengan manager marketing PT Pacific Express Cargo, 20 November 2019. 
memberitahukan bahwa barang tersebut tidak dapat sampai ke tujuan tepat waktu karena suatu hal tertentu seperti cuaca yang buruk, penjelasan tersebut memberikan penerangan kepada kita bahwa suatu perjanjian merupakan hal yang amat penting sebagai aturan yang wajib untuk dipatuhi oleh kedua belah pihak,

Doktrin yang digunakan terhadap kasus kehilangan ataupun keterlambatan pengiriman barang pada konsumen adalah privity of contract yang memiliki pengertian bahwa tanggung jawab seorang pelaku usaha guna mengganti kerugian yang diterima konsumen hanya sebatas dengan apa yang telah disepakati dalam perjanjian serta sebaliknya konsumen wajib mendapatkan perlindungan dari pelaku usaha sebatas pelaku usaha dan konsumen tersebut terikat dalam suatu perjanjian, adapun batas tanggung jawab dari PT. Pacific tersebut hanya pada pemrosesan dokumentasi barang yang rusak atau hilang sebelum dialihkan kepada Mitra Asuransi untuk melakukan claim asuransi terhadap kerusakan ataupun hilangnya barang tersebut, serta terkait keterlambatan barang bentuk tanggung jawab dari PT. Pacific terhadap konsumen terbatas hanya pada pemberitahuan kepada konsumen terkait penyebab barang tersebut terlambat dan memberikan dokumentasi berupa foto pada konsumen.

Prinsip tanggung jawab yang digunakan terhadap kehilangan ataupun kerusakan saat pengiriman barang yang diterima konsumen pada PT. Pacific adalah prinsip tanggung jawab dengan pembatasan yang memiliki pengertian dalam suatu perjanjian pelaku usaha dapat menentukan tanggung jawabnya atau dapat dibatasi sampai mana tanggung jawabnya dapat dilaksanakan yang tentu harus berdasarkan kesepakatan dengan konsumen, bukti prinsip tanggung jawab dengan pembatasan pada PT. Pacific sendiri dapat dilihat pada awal perjanjian antara konsumen dengan PT. Pacific bahwa PT. Pacific menentukan tanggung jawabnya hanya sebatas memproses dokumentasi kerusakan ataupun kehilangan barang yang diterima konsumen.

\section{B. Penyelesaian Sengketa PT. Pacific Express Cargo terhadap} Keterlambatan dan/atau Hilangnya Barang pada Konsumen

Kegiatan jual beli barang atau jasa pasti tidak terlepas dengan namanya sengketa, setiap sengketa yang terjadi selalu menuntut 
pemecahan dan penyelesaian yang tepat sehingga diperlukan alternatif penyelesaian sehingga sengketa yang terjadi tidak berkepanjangan, menimbulkan kerugian yang besar dan tercapainya keadilan para pihak bersengketa. Menjawab penyelesaian sengketa yang dapat menjaga hubungan bisnis maka alternatif penyelesaian sengketa melalui non litigasi adalah upaya yang dapat dilaksanakan. Undang-Undang no 30 tahun 1999 tentang Arbitrase dan Alternatif Penyelesaian Sengketa Pasal 1 angka 10 menjelaskan bahwa alternatif penyelesaian sengketa adalah "cara penyelesaian sengketa atau beda pendapat melalui prosedur yang disepakati para pihak, yakni penyelesaian di luar pengadilan dengan cara, konsultasi, negosiasi, mediasi, konsiliasi, atau penilaian ahli”. Penyelesaian sengketa terkait keterlambatan barang pada konsumen yang dilakukan oleh PT Pacific sendiri dijelaskan oleh Pak Komang selaku Manager Marketing PT Pacific Express Cargo adalah melakukan negosiasi dan dalam Teori Dean G. Pruitt dan Jeffrey Z. Rubin tentang teori penyelesaian sengketa mengenai lima strategi penyelesaian sengketa, adapun kelima strategi penyelesaian sengketa tersebut adalah contending (bertanding), yielding (mengalah), problem solving (pemecahan masalah), withdrawing (menarik diri), dan inaction (diam), ${ }^{11}$ dan dari kelima strategi yang dikemukakan Dean G. Pruitt dan Jeffrey Z. Rubin strategi negosiasi yang digunakan PT. Pacific adalah problem solving (pemecahan masalah) yang mana dari pihak PT. Pacific sangat mengutamakan kepentingan konsumen sehingga dibutuhkannya pemecahan masalah dengan pihak penerima barang baik itu mengenai penjadwalan ulang terhadap sampai barang ke tujuan yang harus menyesuaikan dengan jadwal penerima barang dan penyebab dari pengiriman barang tersebut tidak dapat sampai tepat waktu $^{12}$ biasanya terjadi pada pengiriman barang melalui jalur udara dan laut dikarenakan cuaca yang buruk yang menyebabkan delay pada pengangkutan barang tersebut, selain hal tersebut terdapat upaya lain yang dilakukan oleh PT Pacific terhadap keterlambatan yang terjadi di kemudian hari yaitu dengan melakukan upaya pencegahan dengan menganalisis pengiriman barang mengenai kapan barang tersebut sudah harus sampai

11 Khoirul Anwar, 2018, Peran Pengadilan dalam Arbitrase Syariah, Kencana", Jakarta, h. 25.

12 Wawancara dengan manager marketing PT Pacific Express Cargo, 20 November 2019. 
ke tujuan, booking transportasi, dan menghitung waktu berapa lama barang tersebut telah sampai di pelabuhan ataupun bandara sebelum selanjutnya dikirimkan langsung kepada penerima barang, sedangkan terkait dengan kehilangan barang penyelesaian sengketa yang dilaksanakan oleh ekspeditur dengan penerima barang adalah sama dengan keterlambatan barang yakni melalui negosiasi tetapi poin yang didiskusikan adalah apabila terdapat komplain dari konsumen PT. Pacific memberikan penjelasan kembali dari perjanjian yang telah disepakati bersama terkait kehilangan dan kerusakan barang adalah asuransi yang bertanggung jawab dalam hal ini Mitra Asuransi yang wajib mengganti barang yang rusak ataupun hilang dengan sejumlah uang sesuai nilai barang yang telah hilang.

\section{KESIMPULAN}

1) Tanggung jawab PT Pacific Express Cargo terhadap keterlambatan dan kehilangan barang yaitu didasari dengan suatu perjanjian yang dimana terhadap keterlambatan barang bentuk tanggung jawab dari PT Pacific adalah terus memberitahukan kabar dari barang yang dikirimkan sampai ketujuan dan apabila terdapat hambatan diperjalanan pihak PT Pacific melakukan dokumentasi berupa foto dan komunikasi melalui aplikasi whatsapp untuk memberitahukan bahwa barang tersebut tidak dapat sampai ke tujuan tepat waktu karena suatu hal tertentu seperti cuaca yang buruk, sedangkan tanggung jawab PT Pacific terhadap kerugian baik itu kehilangan atau kerusakan pihak asuransilah yang bertanggung jawab terhadap kerusakan tersebut dengan membayar premi sejumlah $2 \%$ dari nilai barang milik pengirim, adapun perusahaan asuransi yang bekerja sama dengan PT Pacific terkait terjadinya kerugian baik itu kehilangan ataupun kerusakan barang adalah Asuransi Mitra, dan untuk claim asuransi terhadap adanya kerusakan dan kehilangan barang tersebut dari pihak penerima barang dapat melampirkan foto terkait barang yang rusak ataupun barang yang hilang dan dari pihak PT Pacific sendiri akan memproses hasil dokumentasi berupa foto dari penerima barang dengan membuat surat claim asuransi terkait hilang ataupun rusaknya barang kepada Mitra Asuransi setelah itu pihak asuransi akan memproses pengganti kerugian kepada penerima barang sebesar kerugian yang diterima oleh penerima barang 
tersebut tetapi tidak melebihi $2 \%$ dari jumlah asuransi yang telah dibayarkan sebelumnya oleh pengirim barang.

2) Penyelesaian sengketa yang dilakukan oleh PT. Pacfic terhadap keterlambatan pengiriman barang adalah melakukan negosiasi dengan pihak penerima barang mengenai penjadwalan ulang terhadap sampai barang ke tujuan yang harus menyesuaikan dengan jadwal penerima barang dan penyebab dari pengiriman barang tersebut tidak dapat sampai tepat waktu yang biasanya terjadi pada pengiriman barang melalui jalur udara dan laut dikarenakan cuaca yang buruk yang menyebabkan delay pada pengangkutan barang tersebut, sedangkan terkait kehilangan barang yaitu dengan negosiasi tetapi poin yang didiskusikan adalah apabila terdapat komplain dari konsumen PT. Pacific memberikan penjelasan kembali dari perjanjian yang telah disepakati bersama terkait kehilangan dan kerusakan barang adalah asuransi yang bertanggung jawab dalam hal ini Mitra Asuransi yang wajib mengganti barang yang rusak ataupun hilang dengan sejumlah uang sesuai nilai barang yang telah hilang

Adapun saran yang diberikan adalah perlu diberikannya edukasi bagi seluruh masyarakat Indonesia akan pentingnya suatu perjanjian dalam melaksanakan kegiatan jual beli dikarenakan dalam perjanjian tersebut banyak hal-hal yang penting terkait hak-hak dan kewajiban para pihak, hal lainnya yang menjadi saran setelah dilaksanakannya penelitian ini adalah perlu diterapkannya penginformasian kembali kepada konsumen terhadap keterlambatan pengiriman barang seperti yang dilaksanakan oleh PT. Pacific Express Cargo dikarenakan masih banyak perusahaan yang tidak memberikan keterangan terhadap keterlambatan pengiriman barang sehingga konsumen merasa ragu akan keberadaan barang tersebut akankah sampai ketujuan atau tidak. 


\section{DAFTAR PUSTAKA}

\section{Buku:}

Khoirul Anwar, 2018,Peran Pengadilan dalam Arbitrase Syariah, Kencana, Jakarta.

H.M.N Purwosutjipto, 2000, Pengertian Pokok Hukum Dagang Indonesia, Cetakan ke 3, Djambatan, Jakarta.

Zainal Asikin, 2014,Hukum Dagang, Rajagrafindo Persada, Jakarta,

Ridwan Khairandy, Machsun Tabroni, Ery Arifuddin, dan Djohari Santoso, 1999, Pengantar Hukum Dagang Indonesia, Jilid 1, Gama Media, Yogyakarta.

\section{Peraturan Perundang-Undangan}

Kitab Undang-Undang Hukum Dagang

Kitab Undang-Undang Hukum Perdata

Undang-Undang No. 8 tahun 1999 tentang Perlindungan Konsumen

\section{Internet}

https://id.wikipedia.org/wiki/Keadaan_kahar(11/23/2019 11:53 AM)

https://bali.bps.go.id/pressrelease/2019/02/01/717229/perkembangantransportasi-udara-dan-laut-provinsi-bali-desember2018.html(9/21/2019 8:46 PM) 